\title{
Cultivating ambivalence
}

\section{Some methodological considerations for anthropology}

\author{
Ciara Kierans, University of Liverpool \\ Kirsten BELL, University of Roehampton
}

Anthropologists' longstanding ambivalence toward political advocacy has, in recent years, come under sustained fire-a shift that is often framed in terms of the discipline's "moral turn." In this essay, we make a case for the value of ambivalence, asking what lessons it yields as a methodological heuristic. Tracing the history of the concept, we argue that anthropology was founded on an epistemological ambivalence regarding its orientation to social problems. Thus, the moral turn implies a fundamental transformation in the ways that ethnography is conceived. Although the possibility of conflating moral evaluation with anthropological interpretation is a recognized danger of this shift, we don't believe that the problem can be resolved by being reflexive, or that all ethnographers confront it. Instead, we suggest that cultivating an analytic of ambivalence is our best strategy for understanding what is going on around us, and teaches us more about the character of social relations than prefigured moral stances can.

Keywords: morality, ethics, moral anthropology, ambivalence, methodology

We learned that Boycott supporters felt silenced and intimidated by the antiBoycott sentiment in their departments while on the other hand anti-Boycott supporters felt silenced and intimidated by the Boycott sentiment in their departments.

...

We learned that everyone cared because turn out was at an all time high or

We learned that no one cared because only half the association votes

...

We learned the other side couldn't see how far right it was unless

The other side couldn't see how far left it was.

This work is licensed under the Creative Commons

| (c) Ciara Kierans and Kirsten Bell.

ISSN 2049-1115 (Online). DOI: http://dx.doi.org/10.14318/hau7.2.006 
The boycott was against anthropology's commitment to relativism, tolerance, and dialogue and

The boycott was part of anthropology's commitment to social justice.

...

We learned we couldn't talk because politics is when the time for talking is past and

We learned we should have talked more because talking is what politics is. (Alex Golub 2016)

On June 7, 2016, 51 percent of members of the American Anthropological Association (AAA) narrowly rejected a proposed academic boycott of Israeli institutions by 2,423 votes to 2,384 . The decision to bring the vote to the AAA membership was an outcome of prior petitioning, debate, and deliberation. At the previous 2015 AAA business meeting, the Israel-Palestine conflict had been the central focus of discussion, as a matter of critical concern for anthropologists and their commitment to addressing contemporary social problems. What was at stake at this meeting and the subject of protracted discussion was not the nature of the Israeli occupation, but the particular strategies by which academic objections to it could best be pursued, that is, through boycott or dialogue.

Voting on the resolution to boycott Israeli academic institutions occurred the following spring over a six-week period. During this time, leading academics engaged in advocacy and persuasion and argued their case: to boycott, or not. Many did so via insightful, impassioned, and thoughtful accounts, treating the issue in its complexity and highlighting its profound human importance. Others were rancorous and moralizing, making evident the polarizing effect of the vote (see Hirschkind 2016; Starrett 2016). The outcome and stance taken by the "anthropological community" was eagerly followed by activist groups and campaigners worldwide, turning professional concerns into very public matters.

What the heated discussions about the boycott and the final tally itself illustrated was the profound ambivalence within the anthropological community, wonderfully captured by Alex Golub's (2016) poetic reflection in the opening epigraph. Although some anthropologists were firmly positioned on one side or other of the divide, collectively we struggled to make up our minds-and many of us (including both authors) felt personally ambivalent about the boycott. While similarly wishing to exercise moral outrage at the systematic denigration of the Palestinian people, we were concerned that boycotts offer an oversimplification of events, which makes it difficult to engender solidarities across geopolitical fault lines.

As leading anthropologists argued their cases in the run-up to the AAA vote, often conveying their own misgivings, we were led to reflect on the sense in which national boycotts of academic work constitute a response to the complexities of the situations in a particular society or nation-state. Few anthropologists would hold that states and societies can be treated as monoliths - that they can be read as single, unified entities-yet that is precisely what the proposed boycott asked us to do. We then asked to what extent the collective moral positions we have taken through the AAA vote were grounded in a firm understanding of the situations at hand: What does it mean for an anthropological community to take a moral rather than an analytical stance? 
Ambivalence arises as a product of taking stances. It is at the heart of attempts at position taking. As political theorist Alena Ledeneva suggests, it has its roots in bipolarity and can be understood through the paradoxes bipolarity produces: that is, the contradictory nature of constraints and the informal practices needed to resolve them (Ledeneva 2014b). The more we steer toward polarized understandings, the easier it is to lose sight of the everyday ambivalences which underlie our ways of making sense of the world and acting upon it. Attending to the dilemmas posed by deciding "whose side we are on," as the sociologist Howard Becker (1967) once put it, can alter the character of anthropology itself, fostering new "alignments" (Marcus 2008). It can reposition the objects of our interests as inherently and clearly moral, and, in so doing, set limits on our analytical possibilities. It can make invisible the intricacies of social practice and, to borrow from Bruno Latour (2005), mistreat matters of concern as matters of (moral) fact.

In this article, we extend recent interest in this journal in the concept of ambivalence and the study of contradictions (see Berliner et al. 2016; Jovanović 2016) to ask what lessons ambivalence, as a feature of everyday social practice, has for anthropology. We take up these questions by refocusing on the value of ambivalence as a contemporary methodological heuristic. In what follows, we discuss the ways in which ambivalence has featured as a significant concept in the behavioral and social sciences generally and anthropology specifically. We then prepare a case for ambivalence via the "moral turn" in anthropology and two critical cases taken from our own research. We conclude by recasting ambivalence as a methodological heuristic in anthropology, one which we argue has vital analytical significance.

\section{Locating ambivalence in fields of understanding}

Outside of anthropology, social scientific explorations of ambivalence can be seen as following two distinct, albeit interrelated, paths: one, psychological; the other, sociological. In the psychological literature, ambivalence is broadly defined as "overlapping approach-avoidance tendencies, manifested behaviorally, cognitively, or affectively, and directed toward a given person, experience, or other object, as well as toward a set of objects" (Sincoff 1990: 43-44). It is typically seen to be an undesirable state-one that results in distress and/or an inability to make a decision (ibid.).

These negative connotations emerged as psychoanalysts developed the concept. Although strongly associated with the work of Sigmund Freud, it was Eugen Bleuler who introduced the term into scientific parlance (Merton 1976; Sincoff 1990). In a 1911 lecture on schizophrenia, he described ambivalence as one of its fundamental symptoms, differentiating between three primary types: volitional, intellectual, and affective. Volitional ambivalence relates to conscious conflicts, such as when someone both wishes and doesn't wish to eat. Intellectual ambivalence, on the other hand, is largely unconscious and primarily manifests itself linguistically_-such as when an idea and a counteridea are expressed in the same sentence (e.g., "frenemy"). Finally, affective ambivalence involves simultaneous feelings of love and hate directed toward the same object; the example Bleuler provides is of "the husband both loves and hates his wife" (cited in Bleger 2013: 246). 
Bleuler did not see ambivalence as intrinsically pathological. In his words, "Even for the healthy everything has two sides. The rose has its thorns. But in ninetynine out of a hundred instances, the normal person compares the two aspects, subtracts the negative from the positive values. He appreciates the rose despite its thorns" (cited in ibid.: 374). For Bleuler, the pathology occurred when these two perspectives were not synthesized: "The schizophrenic, with his weakened associative linkings does not necessarily bring the different aspects of a problem together. He loves the rose because of its beauty and hates it because of its thorns" (cited in ibid.).

Freud developed these ideas in his work on transference, although he focused exclusively on affective ambivalence (Sincoff 1990; Raulin and Brenner 1993). Although Freud acknowledged that "ambivalence of feelings appears to be normal up to a point," in his view "a high degree of it is certainly a special peculiarity of neurotics" (Freud [1912] 1958: 320). For Freud, ambivalence became pathological when the opposing feelings were equal in strength or when the emotion was particularly intense (Raulin and Brenner 1993).

Today, schools of psychoanalysis differ in the extent to which they characterize ambivalence as pathological, with object-relation theorists more likely to treat it as a healthy developmental achievement than a pathological response (Sincoff 1990). Nevertheless, in light of its significance in the context of psychopathology and personality disorders (e.g., schizophrenia, depressive disorders, and obsessivecompulsive personalities), it largely operates as something to be resolved or worked through. In Julie Sincoff's words: "Recognizing ambivalent conflicts and working towards resolution or acceptance of such conflicts thus constitutes a major psychotherapeutic task for clinicians and their patients" (1990: 48).

Ambivalence, however, is not a simply a problem of mind, a psychological "fact," but also has its social counterparts and can therefore be understood as a social factas Durkheim might hold. This line of analysis was taken up in the work of Robert Merton (1976). Merton introduced the concept of sociological ambivalence as complementary to the notion of psychological ambivalence. Arguing that "the facts of ambivalence have been regarded chiefly or wholly in their psychological aspects" (ibid.: 4), he aimed to make the structure of social relations, and its role in producing ambivalence, the focus of sustained analysis. His chief interest was in the "ways in which ambivalence comes to be built into the structure of social statuses and roles" (ibid.: 5) - understood in terms both of the processes that affect the probability of ambivalence occurring and of the consequences of such ambivalence for the workings of social structures. Ambivalence reflects the contradictory demands placed upon people in society, signifying the importance of dualism, contradiction, and paradox for social analysis. These consequences Merton saw in primarily negative terms.

However, because the conflicts produced were rooted in the social structure rather than the individual psyche, they couldn't necessarily be conquered or resolved. Although this exteriorized view of ambivalence as a "problem" to be diagnosed (and solved), one having psychological undertones, has indelibly marked the ways we discuss and use the concept in anthropology and sociology (Nedelmann 1998), several analyses have presented us with more complex and nuanced perspectives. In these accounts, ambivalence is portrayed as something produced by (and productive of) our orientation to the social world, rather than constituting an 
explanatory device in and of itself. This distinction, which can be subtle, is critical to the argument of this article.

Zygmunt Bauman's Modernity and ambivalence (1991) is an ambitious attempt to grapple with the transition from the modern to postmodern condition, which he suggests is characterized by greater social fragmentation and, as a result, greater tolerance for ambivalence. We are not interested in pursuing this broader line of argument here; however, where we see Bauman's work as relevant is in his observations about ambivalence as a byproduct of the drive toward order and classification. Classification is premised on the assumption that the world consists of discrete entities that are opposed to other entities; its logic is that of inclusion and exclusion-of bifurcation and dichotomization. It thus seeks to eradicate ambivalence by its ordering and structuring practices. But "the application of such criteria, and the very activity whose progress they are to monitor, are the ultimate sources of ambivalence" (ibid.: 7). That is to say, ambivalence is produced by the very same processes that seek to overcome it. The drive to eradicate ambivalence is therefore both self-perpetuating and self-defeating.

These dual qualities of ambivalence as something that simultaneously advances and defeats fixity are illustrated in Homi Bhaba's (1984) work on mimicry and colonial discourse. Bhabha argues that mimicry is a mode of colonial discourse that desires the production of a "reformed, recognizable Other, as a subject of difference that is almost the same, but not quite" (ibid.: 126, emphasis in original). Thus, the discourse of mimicry is constructed around an ambivalence: "In order to be effective, mimicry must continually produce its slippage, its excess, its difference" (ibid., emphasis added). But this double vision means that mimicry has the potential to disrupt the authority of colonial discourse even as it aims to reproduce it. Again, we see the ways in which ambivalence destabilizes the very categories it is premised upon.

This destabilizing force of ambivalence is also recognized within the science and technology studies literatures (Singleton and Michael 1993), undermining both the hubris and determinism often associated with scientific innovation and development. New technologies such as nanotechnologies, advanced reproductive technologies, and transplant medicine are often imagined by both scholars and the public in relation to their good or bad effects on the world: their capacities to liberate or enchain (Rabinow 1996; B. S. Turner 2007). This is particularly evident in feminist ambivalences toward plastic surgery, simultaneously conceived of as a powerful tool for and against women, "desirable and problematic" (Davis 1995: 180).

These bifurcations are, of course, not written into the technological forms themselves; nor are they a consequence of them, making oscillations between optimism and pessimism analytically unproductive (Wajcman 2004). Technologies, as Marianne de Laet and Annemarie Mol (2000) artfully show in their writing on the Zimbabwe bush pump type B, are intrinsically ambivalent as to their effects-to their being loved or despised. It is instead our orientations to them, the complex social relations within which they are embedded, and, from this, the social contexts within which they are made to work or fail, which produce their effects upon the world. In other words, this complex social ground provides the conditions of and for ambivalence, and is no less a feature of anthropological scholarship and its technologies of knowledge production than it is of de Laet and Mol's water pump. 


\section{Ambivalence and anthropology}

As the response to the proposed AAA boycott of Israeli institutions suggests, there is a considerable degree of ambivalence about the relationship between anthropology and political advocacy. This ambivalence speaks to two very different orientations to the discipline-differences that crystallize in a comparison of several papers published in the 1990s on anthropology and advocacy.

In an article titled "Anthropological advocacy: A contradiction in terms?," Kirsten Hastrup and Peter Elsass argued that

advocacy, as such, is incompatible with anthropology as a distinct kind of scholarship. To be advocates anthropologists have to step outside their profession, because no "cause" can be legitimated in anthropological terms. Ethnographic knowledge may provide an important background for individual advocacy for a particular people, but the rationale for advocacy is never ethnographic; it remains essentially moral in the broadest sense of the term. (1990: 301)

Less than a year later, Orin Starn (1991) made precisely the opposite plea. With reference to Andean anthropology, he pointed to the ways in which ethnographers often mentioned the high rates of infant mortality, minuscule incomes, poor life expectancy, inadequate diets, and so on, only in passing, choosing instead to reproduce a "Andeanist" variant of Orientalism that focused on ceremonial exchanges, weddings, baptisms, and so on, and highlighted continuities with a precolonial past. He concluded:

Active anthropological work for life and peace ought, I believe, to accompany the break from Andeanism. If the effects may be small, our efforts can at least help to bring Peru's situation to public attention and to build pressure on the Peruvian government to respect human rights.

(1991: 86)

In sum, for Hastrup and Elsass, advocacy was fundamentally unanthropological; for Starn, advocacy was anthropologically necessary-a critical means of undoing the damaging anthropological representations of Andeans.

A similar debate played out a few years later with a slight change in personnel. In 1995, Nancy Scheper-Hughes presented her proposal for a "militant" anthropology. Citing Starn, she argued that it was untenable for anthropologists to continue to position themselves as above and outside the human events they recorded. Instead, she advocated a view of the anthropologist as "a responsive, reflexive, and morally committed being, one who will 'take sides' and make judgments" (ibid.: 419). To do otherwise, she suggested, was to collaborate with "the relations of power and silence that allow the destruction [of dominated peoples] to continue" (ibid.: 319).

In a response to the piece, Roy D'Andrade (1995) raised a number of concerns about the growing emphasis on anthropology as a moral discipline that contained explicit moral judgments about the world. Differentiating between a "moral model" and "objective model" of anthropology, he interrogated the assumptions underpinning the former. Singling out its inability to provide an adequate representation of the world, its underlying ethnocentrism, and its implicit objectivism, D'Andrade 
argued that "anthropology can maintain its moral authority only on the basis of empirically demonstrable truths" (ibid.: 408).

It is tempting to characterize these differing assessments largely as evidence of a generation gap, with Hastrup, Elsass, and D’Andrade standing in for the old guard and Starn and Scheper-Hughes standing in for the new. Indeed, the position of Hastrup and Elsass and of D’Andrade now appears a little dated and naïve, seeming to draw on an ideological separation between "facts" and "values" that the postmodern, postcolonial, poststructuralist turn decisively shattered (see Pels 1999).

In recent years, anthropologists have answered Starn's and Scheper-Hughes' criticisms by providing an expansive corpus of studies-critical and applied in character-on what we might broadly refer to as social problems, which we will go on to discuss shortly. However, in our view, it would be a mistake to represent these debates as particularly new. In fact, we want to suggest here that they speak to an epistemological ambivalence built into anthropology-one that was foundational to the discipline's formation and professionalization.

Peter Pels has argued that anthropology's morals are essentially duplex: "Without duplicitous intent or moral corruption, anthropologists cannot but adopt 'double standards"' (1999: 102). It was such duplexity-and the ethical and epistemological doubling it entailed-that enabled anthropologists to simultaneously serve and distance themselves from the colonial administrations that both facilitated and were the primary consumers of anthropological research.

Pels argues that the process of anthropological professionalization was intimately tied up with an attempt to distance the discipline from its prior problem-oriented agenda in service of the colonial enterprise. This took the form of "a morality of representation: the argument that only a disinterested, noninterventionist attitude in the field could reduce the duplexity of fieldwork and lead to an adequate knowledge of the colonized" (ibid.: 108). But Pels observes that the morality of representation could work out in two seemingly contradictory ways: as a commitment to practical relevance and as "pure" scientific detachment. This is thus the basis for anthropology's ambivalent relationship to championing social causes and solving social problems. ${ }^{1}$

It is this ambivalence that propelled early disciplinary discussions about the merits of applied anthropology (see Evans-Pritchard 1946) and later questions about the possibility of a "feminist ethnography" (see Stacey 1988; Abu-Lughod 1990). More recently, it has informed debates about the precise role and contributions anthropology can make under the mantle of "public anthropology" (Borofsky 2000), which has developed alongside debates about "public sociology" (Burowoy

1. However, it's not clear that all anthropologists experienced this ambivalence equallyor at least not in the same way. Franz Boas exemplifies an anthropologist whose political and scientific commitments were firmly wedded in his work. For example, in a much-cited passage at the end of The mind of primitive man, he noted: "I hope the discussions outlined in these pages have shown that the data of anthropology teach us a greater tolerance of forms of civilization different from our own, that we should learn to look on foreign races with greater sympathy" (1911: 278). Nevertheless, he arguably saw his scientific work as intellectually separable from his advocacy efforts, whilst simultaneously aware of how they informed each other. 
2005) and "militant anthropology" (Scheper-Hughes 1995). However, the standpoints adopted suggest a concern not only for the anthropologist as advocate but also for the transformative potential of anthropology itself (Osterweil 2013). In what follows, of particular interest to us is the growing insistence that anthropological work requires a more pronounced moral compass.

\section{Prefiguring engagement: Social problems and the "moral turn"}

Didier Fassin $(2008,2012)$ observes that moral indignation has become a major influence on the choice of topics that anthropologists study. In his words:

Two or three decades ago, anthropologists did not work on violence and suffering, trauma and mourning, prisons and camps, victims of wars and disasters, humanitarianism and human rights. These realities existed but received little attention from the discipline. Other objects, whether kinship or myths, witchcraft or rituals, peasantry or development, were seen as more relevant for the understanding of human societies. This transformation of our gaze and of our lexicon has been accompanied by frequently more engaged positioning. Such a remarkable evolution raises the question of why we were unaware of or indifferent to the tragic of the world before and, symmetrically, why we became so passionately involved in it in recent years. (Fassin 2012: 5)

Fassin thus points to a moral hierarchy of legitimate objects of anthropological research that increasingly dictates what anthropologists study and how (Caduff 2011).

Although Fassin suggests this development is specific to the discipline, Kirsten Bell (in press) has elsewhere suggested that the so-called "moral turn" might be better read as an instrumental one that is evident well beyond the confines of anthropology. For example, Marilyn Strathern (2005) has highlighted the ways that "society" had increasingly been drawn into the scientific enterprise as a key "stakeholder." This, she suggests, has encouraged "problem-oriented, task-specific, research-tofind-solutions types of questions" (ibid.: 13). The net result is that academics from all disciplines are expected to focus on research that contributes in a direct way to solving social, economic, and cultural challenges and problems (Dehli and Taylor 2006). As Bruce Kapferer has observed, "The major problem with some views concerning new developments in anthropology and cognate disciplines is a failure to examine them against processes occurring in the wider global political scene" (2000: 175).

Regardless of the forces driving the shift in focus, it's nevertheless clear that certain topics are increasingly morally prefigured in terms of how anthropologists - and others - are expected to engage with them. We therefore agree with Fassin's concerns about the analytical constraints that moral positions can and do impose, although this point is far from new, having repeatedly reared its head in the longstanding disciplinary debates about anthropologists' orientation to advocacy. Where Fassin differs from earlier commentators is in his view that anthropological research is inherently moral. In his words, "All human activities are grounded on moral assumptions" (2012: 5); therefore, "we have to live with it" and "work on it" (2008: 342). 
We are less convinced that anthropological research is unavoidably moral - unless morality is treated as synonymous with "values." This is precisely the position Fassin takes, as he continually speaks of "moral positions" and "value judgements" in the same breath, in what amounts to a conceptual collapse of both terms (e.g., ibid.: 337, 341). Indeed, he explicitly avoids defining the term "moral," justifying this via recourse to the lack of philosophical agreement on its meaning and "because for social scientists there is a benefit from proceeding in this inductive way" (Fassin 2012: 6). However, it seems to us that more specificity is necessary, because while all research may be value laden, it is clearly not all morally driven-as Fassin himself observes, the moral indignation that increasingly characterizes anthropological research is relatively new.

Here, the early work of the anthropologists Abraham and May Edel is useful in articulating the differences between values and morals. ${ }^{2}$ In Anthropology and ethics, they observed that in some respects "we all know what we are talking about when we talk about morality," but went on to ask: "By what mark shall we know 'the moral'?" (1959: 7). In their account, morality is somewhat akin to pornography insofar as we might all know it when we see it (to paraphrase the famous quote by US Supreme Court Justice Potter Stewart), but we don't all have the same view of what it is.

Edel and Edel argued that there was considerable diversity in how the mark of the moral was assigned, and highlighted two distinct conceptual variants: "Ethics Wide" and "Ethics Narrow." Ethics Wide "assumes that moralities are part and parcel of the whole field of human endeavor and striving" (ibid.: 8). In this framing, human "values" writ broad are of interest; these values might be explicitly moral, or they might be those that play an organizing role in society, or they "may have no particular unity beyond some broad servicing role in the achievement and maintenance of fundamental individual and social well-being" (ibid.: 9). In contrast, Ethics Narrow limits the scope of inquiry into moral phenomena by emphasizing the notion of duty or obligation. In Edel and Edel's words, "Values, it says, are far too broad, far too promiscuous. Only those that ought to be or ought to be realized come within the scope of morality" (ibid., emphasis in original).

Although Edel and Edel suggest that Ethics Wide is too broad and Ethics Narrow is too confined to suit the task of the comparative study of morals, Signe Howell (1997) points out that Ethics Wide effectively becomes a stand-in for the concept of "culture." Likewise, the problem with Fassin's definition of moral anthropology is that potentially anything and everything is included in its scope (Bell in press). In our view, this has the effect of disguising what is distinctive about the newly moral(istic) variant of anthropology. In fact, it seems to us that this is precisely what some of the earlier critics of the moral turn in anthropology were primarily concerned about, although they are often represented as naïvely clinging to an outdated ideal of scientific detachment and objectivity.

For example, despite the seemingly dated contrast D’Andrade (1995) draws between an "objective" and "moral" model of anthropology, he doesn't claim that

2. Although they muddy the waters slightly by treating "morals" and "ethics" as synonyms. This is a common tendency, albeit one that Quetzil Castañeda (2006) challenges on conceptual grounds. 
anthropology is value-free or that the purposes to which it is put are always benign. Instead, his concern is with the rise of an overtly moral version of the discipline that aims "to identify what is good and what is bad and to allocate reward and punishment"3 (ibid.: 399, emphasis in original). If, as Fassin himself notes, "moral discourse evaluates, judges, sanctions" (2008: 339), then clearly not all anthropological discourse is moral in this specific sense, because its goal is understanding rather than evaluation. Thus, there is clearly a qualitative difference in the ways that anthropologists write about certain topics in comparison to others-as we have frequently had cause to witness in our respective work on tobacco and organ transplantation.

\section{Unpicking the moral imperative}

Today, it has become a truism that cigarettes are the only legal product that "kills" at least one third of all users. Implicit in this framing is the tobacco industry's culpability in producing a lethal and highly addictive product-a view that is captured in a plethora of books with titles like Merchants of death: The American tobacco industry, Peddling poison: The tobacco industry and kids, and Golden holocaust: Origins of the cigarette catastrophe and the case for prohibition and films like The insider.

Such representations are unquestionably related to the tobacco industry's long history of obfuscating the harms of its products and its repeated attempts to impede efforts to regulate them. However, they have also served to construct tobacco use as a quintessentially moral "problem"-one in which the "bad guys" (the tobacco industry) and the "good guys" (tobacco control) are arrayed at the outset and our orientation to the subject matter has been essentially preordained.

Because the starting point is the undesirable character of tobacco use and the tobacco industry's responsibility for its uptake, this framework "promotes an understanding of tobacco use that makes reference to the tobacco user and his/her practices analytically redundant" (Mair and Kierans 2007: 107). After all, the answer to the question of why people smoke is assumed from the outset. As Simone Dennis (2016: 13) observes, “The 'why people smoke' question is almost invariably asked in the service of the 'how can it be stopped?' question; the question is, in other words, asked to generate an answer useful to the project of smoking cessation." In effect, tobacco research "proper" becomes defined by its commitment to ending the global tobacco "epidemic" - or, at the very least, its capacity to resist appropriation by the tobacco industry (Mair and Kierans 2007). The end result is that tobacco research becomes largely instrumental in function (ibid.; Bell 2013; Bell and Dennis 2013; Dennis 2016).

3. Half a century earlier, Evans-Pritchard (1946: 92) made essentially the same point, noting: "It is surely not required of an anthropologist that he have no moral values or shall refrain from using them in situations which demand an ethical standard. What is objectionable is for an anthropologist to allow his particular philosophy to determine his observations, to influence his deductions, and dictate his problems within the field of his own science." 
A radically different domain which produces similarly polarized points of departure across various fields of understanding is that of organ transplantation. From a medical perspective, organ transplantation is largely constructed as a public good: the "optimum" treatment for end stage kidney disease, a "gift" of life, the heroic outcome of valiant surgeons, and so on. Such institutionalized narratives have, as Margaret Lock (2002) suggests, been fundamental to the stabilization and public acceptance of transplant medicine, to how it has taken root with little opposition.

Those, however, with an interest in the social relations and mechanisms of exchange on which transplant medicine depends have sought to recast the transplant story in much less positive terms. From popular fiction (e.g., Frankenstein, Coma, Flatlander, Never let me go) to film (e.g., The awful Dr. Orloff, The brain that wouldn't die, Seven pounds, Dirty pretty things) to anthropological research to bioethical debates, various social and cultural responses to transplant medicine have raised a whole host of concerns (Kierans 2011, 2015). These range from organ selling, stealing, and trafficking, to medical malpractice, the deleterious consequences of human experimentation, and the ethics bound up with using brain and cardiac death criteria to support deceased organ donation.

While there are many of bodies of research across the social sciences which take a more nuanced approach to this domain, the temptation has been to attend to this subject matter through its extreme forms (signs of utopian or dystopian futures), and then to read organ transplantation as inherently exploitative and capitalistic in character (Kierans 2011, 2015). As a result, perspectives on transplant medicine are riven by moral position taking and juxtaposition: utopian futures sit alongside dystopian fears, medical valor alongside corruption, care alongside exploitation. These contrasting positions insinuate not only that there are sides to be taken, but that these sides are unproblematic: Who could be against the importance of life-saving technologies? Similarly, who could be for organ trafficking and the exploitation and mutilation of poor bodies? But assuming such moral positions obscures the complex social relations, conditions, and contexts which ground transplant medicine and, in turn, treats the important contributions anthropology can make to an understanding of this issue as anthropology — rather than moral philosophy-as of only secondary importance. We are presented with arguments about which side to take but we are not helped to arrive at a better understanding of what sides are being taken on. Instead, a moral commitment to viewing things in a particular way from the outset becomes the foundation for further inquiry.

Despite their differences, both topics share a tendency for anthropologists to take on the role of moral arbiter. Thus, it seems to us that characterizing all anthropology as driven by moral impulse serves to dilute and elide the larger issuewhich is that the terms of engagement with some topics have been foreclosed and some kinds of conversations have been shut down, effectively limiting our grasp of such phenomena. For example, when we reduce tobacco use or organ transplantation to discourses of exploitation, what have we learned about the nature of smoking or indeed its promotion, or the practices and contexts from which medicine is practiced? We have only explicated part of the problem. While it is easy to refer to specific practices bound up with each as abominations, does calling something an "abomination" make us any more attuned to the nature of the problem at hand? 
At this point, it is important to be clear that we are neither condoning nor turning a blind eye to unscrupulous practices, but concerned about the role of explicit moral positions as academic points of departure and their capacity to shape the critical ground of our research. Operating from moral starting points, as opposed to understanding them as subjects to be explicated, far too easily sets up orthodoxies and symmetries, generating normative assessments that can only take us into analytical culs-de-sac. Worse still, they impose false simplicities, where the agency of others is suffocated, and our chief protagonists, the "good" and "bad" guys, become social caricatures or "dopes" (Garfinkel 1967) passively following prescribed cultural scripts.

In her much-cited essay “Can the subaltern speak?," Gayatri Chakravorty Spivak (1988) attends to this problem by emphasizing those aspects of history and ideology that obstruct and obscure the possibility of being heard for those who inhabit the periphery. In doing so, she also provides a sobering reminder that the critical ground of analysis is not the special preserve of the academic researcher alone, but exists as local idiom, part of everyday lives and responses of others to social problems. In similar fashion, Dorothy Smith (2004: 446) marks the distinction between ideology and science as the difference between treating concepts as "the primitives of theory and treating them as sites for exploring the social relations that are expressed in them." Drawing from the writings of Marx and Engels, she emphasizes the importance of locating our scientific efforts within the practical activities of real individuals-the everyday, the seen-but-un(re)marked-as the concrete ground of research. According to Marx and Engels,

The premises from which we begin are, therefore, not arbitrary ones, not dogmas, but real premises from which abstraction can only be made in the imagination. They are the real individuals, their activity and the material conditions under which they live, both those which they find already existing and those produced by their activity. These premises can thus be verified in a purely empirical way. (Cited in D. Smith 2004: 449)

What Spivak and Smith orient our attention to, as with Marx and Engels before them, is that the objects of social inquiry are always governed by the practical ground of everyday activities and not already abstracted a priori points of departure, readily cast as ideology, dogma, or moral standpoints.

It's worth recalling that this emphasis on the "practical activities of real individuals as the concrete ground of research" was historically the starting point for the ethnographic method (e.g., Malinowski 1922; see also Nader 2011). What differentiated anthropology from other social sciences was the ethnographic imperative and the "primacy given to the ethnographic over the conceptual, interpretational or the abstract-theoretical" (Kapferer 2007: 81). Thus, the moral turn is a clear departure from this starting point; indeed, it provides the foundation of a new starting point. Operating thus, we agree with Fassin that anthropologists should see morality (in its more delimited evaluative sense) as a site of social practice and explicate it, rather than take it for granted. Instead of simply acting out of the imperative to weigh in, we need to ask ourselves what is going on. It is very easy to fall into the trap of taking sides on taking sides, where the "good guys" in the social sciences are the ones who know which side to be on and the "bad guys" don't take sides at all. 
Fassin $(2008,2012)$ argues that the moral turn in the discipline thus requires a more demanding methodology that forces us to become more conscious and critical of our own moral presuppositions. This, he suggests, will help us to respect the epistemological grounds of our work whilst simultaneously preserving its political engagements. In other words, it helps to avoid the trap of conflating anthropological interpretation with moral evaluation. But Fassin is vague on what this more demanding methodology might entail, beyond general exhortations about the need to consider "moral reflexivity as part of our research activity" (2008: 341 ; see also 2012: 4).

As Michael Lynch (2000: 26) has observed, while reflexivity is increasingly being held up as a "methodological virtue and source of superior insight, perspicacity or awareness," it's often difficult to establish just what is being claimed. He points out that contemporary injunctions to "be reflexive" presuppose that reflexivity does something. The underlying assumption is that reflexivity has a kind of critical potency and emancipatory potential that transforms a previously unreflexive condition into something more progressive. However, as Lynch argues, what reflexivity does, what it reveals, what it threatens to expose, and whom it empowers ultimately depends upon who is doing it and how they go about it. Indeed, in a basic sense, all research is reflexive, regardless of its political and methodological aspirations.

Lynch (ibid.: 46) concludes that when we recognize the lack of a single coherent division between reflexive and unreflexive discourse, "reflexivity loses its metaphysical aura and (apparent) ideological potency for empowering theories and rallying movements." Thus, reflexivity in general offers little guarantee of insight or revelation. Viewed in this vein, the "moral reflexivity" Fassin advocates is hardly an antidote to the tendency to conflate analytic and normative assessments. On that basis, rather than train our critical attentions inward to the reflexivities of the researcher as a means to resolve moral positioning, we advocate, via the prism of ambivalence, the need to direct our attentions outward to fully explicating the particular problems at hand.

\section{Recasting ambivalence as a methodological heuristic}

Contra Fassin, we assert that a more demanding methodology is achieved not by becoming more conscious and critical of our own moral presuppositions, but by cultivating ambivalence as an orientation to our work. Here the writings of the anthropologist Deana Jovanović and the political theorist Alena Ledeneva are instructive.

Drawing on her fieldwork in Serbia, Jovanović (2016) has recently explicated the value of ambivalence as a means of understanding our interlocutors' dispositions and the myriad ambiguities and contradictions they experience in their lives. As she illustrates, people frequently hew to sets of dispositions that "cannot come into equilibrium with one another" (ibid.: 4) in their daily lives because of the social, political, and economic conditions in which they are embedded.

It is these conditions which Ledeneva draws out in her writing on the ambivalent future of Ukraine: making it something which has to be opened up, fully embraced, and explicated. Reflecting on contemporary political divisions in the 
region, recently heightened by both Russian and European moves to remilitarize the "East"/"West" border, she states:

While "East" and "West" embark on another cycle of ideological confrontation and political standoff, there is little room left for marginal positions and ambivalent attitudes. ... Yet paradoxically, exactly because it is impossible to achieve a consensus, and because the black-and-white forefront positions over the Crimea and east Ukraine split families, friendships, and international clubs, it is the understanding of grey areas ... that might help define the way forward for Ukraine. (Ledeneva 2014a)

Ledeneva $(2006,2014 b)$ has also demonstrated the methodological and analytical significance of her orientation toward ambivalence in her studies of blat, or what she refers to as Soviet Russia's "economy of favors." Blat, as she describes it, is an informal, practical method for "getting things done" in the context of polarized constraint. Her explanation of this phenomenon is worth quoting at length:

The pervasiveness of blat turned favors into an alternative currency of "mutual help and mutual understanding" needed for the functioning of the non-market economy, and embodied people's frustration with the non-consumerist ideology and political constraints of the centralized planning and distribution. On the individual level, favors delivered by friends, acquaintances, and friends of friends granted solutions to small-time problems. On a societal level, they represented a way out for the Soviet system that struggled to adhere to its own proclaimed principles. .. . The contradictory nature of constraints, and informal practices needed to resolve them, are well reflected in the anecdote about six paradoxes of socialism: No unemployment but nobody works; Nobody works but productivity increases; Productivity increases but shops are empty; Shops are empty but fridges are full; Fridges are full but nobody is satisfied; Nobody is satisfied but all vote unanimously. (Ledeneva 2014b: 15)

Substantively, Ledeneva shows that each of these paradoxes masked its reference to an informal practice and in turn protected Soviet Russia's claims to superiority, while undermining its principles. Methodologically, she shows that analytical distinctions (i.e., bipolarities, moral or otherwise) have little explanatory value outside of the informal practices which are, inevitably, nested within their constraints. It is engagement with everyday informal practices that permits us to see what is going on between the poles, and provides the conditions out of which polar accounts become stabilized. Bipolar accounts are, therefore, not descriptions of the world but an invitation to examine the conditions within which polarized descriptions are made meaningful.

What Ledeneva makes clear is that ambivalence, by definition, presents us with an important methodological paradox. While it foregrounds polarized positions, their apparent clarity provides little help in dealing with the complexities of the social situation at hand, complexities which can only be understood when we resist the choice between positions which seek to deny them. Her own resistance to offering intellectual or "moral" arbitration is of particular analytical interest, as is her refusal to advocate a step backward to offer a view beyond warring perspectives. 
Instead, she steps forward into the murk and indeterminacy that polemics conventionally mask and asks a very simple (anthropological) question: What is going on? Methodological ambivalence is, therefore, a call to explicate phenomena, to not take biopolarities for granted as simply descriptions of the way things are. An orientation toward ambivalence prevents the anthropologist from operating according to fixed positions which can distort his or her understanding of social phenomena. Ambivalence means that we have to accept that things are not readily clear, that we need to learn about the conditions under which something may get called an abomination or not, and about how people come to take up variable positions. Following people who take sides isn't a problem; position taking teaches us something fundamental about the nature of the world. It is when the researcher predicates his or her research on a side taken that problems arise.

We would argue that this is even true-especially true-when conducting research on those topics we find morally objectionable. Benjamin Teitelbaum (n.d.), an ethnomusicologist conducting research on radical nationalism in northern Europe, has some useful reflections on this point. He argues that if ethnographic research is epistemologically rooted in a sense of rapport with those studied, then this commitment remains important even when the subjects of our research are the oppressors rather than the oppressed. As he notes, once our research is driven by "the imperative to goodness," this effectively means that "we have endeavored to ensure that pieces of the human experience will remain for us a mystery."

Teitelbaum readily acknowledges that this morally uncommitted (he provocatively calls it "immoral") approach is not without its own ethical dilemmas, especially given that people often confuse academic interest and personal engagement with political sympathy. But in his view, the benefits of this orientation outweigh the risks. In his words,

I credit alignment with having improved appreciably my insight into a marginalized society that many discuss but few understand. By entering into reciprocal, collaborative, and affectionate relationships with Nordic radical nationalists I grew to occupy a position that was neither insider nor outsider, neither cheerleader nor opponent, and neither an accomplice nor an innocent. It was a position liminal in its ethics as well as in knowledge.

As Jonathan Turner suggests, "When concepts reflect moral biases, if not outrage, they almost always miss the point. They fail to denote key processes accurately; they lose precision and nuance" (2005: 33). In a sense, anthropologists, in our view, require an uncommitted-or at least an agnostic-stance on the "subjects" they study (in all senses of the word). Otherwise, these subjects will remain enigmas: interrogated but impenetrable; observed but not understood.

We contend that the need to cultivate ambivalence in our work has become even more urgent in the face of recent global events such as Brexit and the US election. ${ }^{4}$ On the surface, these events speak of increasingly divided and polarized

4. Further afield, corollaries are to be found in the December 2016 vote in the Italian referendum, the 2015 election of a populist authoritarian government in Poland, and the consolidation of power by the government of Viktor Orban in Hungary (Gusterson 
populations that appear to hold oppositional and mutually irreconcilable positions: conservative vs. liberal, prejudiced vs. progressive, closed vs. open, past- vs. future-oriented, and so on (Boyer 2016). However, to read the commitment of such positions at face value ignores the anomalies that start to pile up in the face of them. For example, to imagine that those who voted for Donald Trump (or Brexit) are "idiots," "gullible," or "xenophobes," or as people wholeheartedly buying into a one-sided message, immediately starts to break down when we delve deeper into the compromised and paradoxical reasonings that lie at the heart of political decision making and indeed political campaigning (see Smelser 1997). Thus, we argue, such polarized positions are an invitation to unpick ambivalences rather than iron them out. ${ }^{5}$

And yet it is hard to resist the temptation to give primacy to such events, as Veena Das (2006) might hold. The election of Trump, as is the case with the Brexit referendum, has been given a special type of authority, particularly by the media but also by anthropologists (see Forte 2016). Both events, Trump and Brexit, seem to exert a pressure upon us to take exclusive stances. This, however, may also be the moment when it is most important to resist the urge. Cultivating an analytic of ambivalence might be our best strategy for understanding what is going on-and arguably teaches us more about the character of social relations than a prefigured moral stance can.

By way of example, Jessica Smith (2017) discusses the popular diagnoses of Hillary Clinton's electoral defeat as the revenge of the white working-class or rural voter-part of a "new politics of resentment" (Cramer 2016). She suggests that explanations for Trump's victory which fall back on homogenized demographics may say more about the myopia of liberal politics and the distractions of a new "theater state" than about these particular voting blocs. She cautions that we need as commentators and anthropologists to explore why we are all vulnerable, not just to Trump's campaign, but to the tropes used to critique it.

Brexit and the US election have prompted critical discussion among the anthropological community about how our own experiences and ideological leanings have shaped our responses. In this, Jeanette Edwards, Angelique Haugerud, and Shanti Parikh (2016) pose an important question: Would we have become so exercised about these events if Clinton had won or the 52 percent had voted instead to remain in the European Union? Taking up precisely this issue, contributors to the Social Anthropology forum "Brexit referendum: First reactions from anthropology" (Green 2016) pushed many readers to consider precisely what aspects of the European Union they were mourning, particularly in the context of forms of austerity that have already had devastating consequences for those at the periphery

2017). Marine Le Pen's presidential run in France might have been added to that list but, in the light of recent results of parliamentary elections, it appears her party has flatlined. Given that this is due to Emmanuel Macron's ascendancy on the back of a policy platform predicated on deregulation and labour market flexibility, the ambivalence appears again.

5. The contradictions and complexities at the heart of Trump and Brexit have been subjected to a range of recent debates within anthropology. As examples, see Edwards, Haugerud, and Parikh (2016); Green (2016); and Hall, Goldstein, and Ingram (2016). 
of European markets. Of course, our implication is not that anthropologists should avoid taking stances, but rather that these stances ought to be the outcome of analytical work and not precursors to it.

\section{Conclusion}

In this essay, we have made a case for reclaiming ambivalence as a valuable heuristic device. Rather than treating it as a psychological "problem" to be "solved," a negative of sorts, we argue that it serves an important methodological function because of the ways it destabilizes the very categories it is premised upon. Indeed, we have suggested that it was central to the professionalization of anthropology itself, which was built on an epistemological ambivalence regarding advocacy. It is precisely for this reason that the recent "moral turn" in the discipline has generated so much debate-not because of our disciplinary discomfort with morals (as Fassin would have it) but because of our ambivalent orientation to them.

We don't believe the problem of conflating anthropological interpretation and moral evaluation is resolved by collapsing morals and values and concluding that this is an inevitable feature of our work. In our view, this serves to simultaneously inflate the larger issue, by treating it as universal, and deflate its effects-whereby differences in kind are treated as that of degree and are dealt with via unreflexive calls to "be reflexive" (itself treated as both self-evident and a self-evident good). Instead, we have suggested that anthropologists should focus their attentions outward rather than inward, cultivating a methodological ambivalence toward their subject matter that investigates polarities rather than taking them for granted as simply descriptions of the way things are.

The agnosticism of ambivalence, particularly in the context of "taking sides," does not let power-its forces or its effects-off the hook. Instead, it is a call for a more rigorous analysis, one which does not confuse a world of delimited stances for a world of significances. In this, we are reminded of Stanley Fish's deliberations on the academic project in his book Save the world on your own time (2008). Perhaps best read as a provocative defense of higher education rather than as a denigration of political stance taking, Fish's work cautions against assuming closed-off truths in favor of the analytical value of resisting and rejecting static textual readings of the world in which we live (Butin 2008). In our view, cultivating ambivalence in our research helps us to avoid such static interpretations of the world, despite their seductive power.

\section{References}

Abu-Lughod, Lila. 1990. “Can there be a feminist ethnography?” Women \& Performance: A Journal of Feminist Theory 5 (1): 7-27.

Bauman, Zygmunt. 1991. Modernity and ambivalence. Cambridge: Polity.

Becker, Howard S. 1967. “Whose side are we on?” Social Problems 14 (3): 239-47.

Bell, Kirsten. 2013. “Whither tobacco studies?” Sociology Compass 7 (1): 34-44. 
In press. "Moral anthropology and apriori annunciations." In Critical interventions: The rise of moral anthropology, edited by Bruce Kapferer. London: Berghahn.

Bell, Kirsten, and Simone Dennis. 2013. "Towards a critical anthropology of smoking: Exploring the consequences of tobacco control." Contemporary Drug Problems 40 (1):3-19.

Berliner, David, Michael Lambek, Richard Shweder, Richard Irvine, and Albert Piette. 2016. "Anthropology and the study of contradictions." HAU: Journal of Ethnographic Theory 6 (1): 1-6.

Bhabha, Homi. 1984. "Of mimicry and man: The ambivalence of colonial discourse." Discipleship: A Special Issue on Psychoanalysis 28 (Spring): 125-33.

Bleger, José. 2013. Psychosis and ambiguity: A psychoanalytic study. Edited by John Churcher and Leopoldo Bleger. Translated by Susan Rogers, Leopoldo Bleger, and John Churcher. Hove: Routledge.

Boas, Franz. 1911. The mind of primitive man. New York: Macmillan Company.

Borofsky, Robert. 2000. "Public anthropology. Where to? What next?" Anthropology News 41 (5): 9-10.

Boyer, Dominic. 2016. “Crisis of liberalism.” Cultural Anthropology (October 27). https:// culanth.org/fieldsights/989-crisis-of-liberalism.

Burowoy, Michael. 2005. "2004 American Sociological Association presidential address: For public sociology.” British Journal of Sociology 56 (2): 259-94.

Butin, Dan W. 2008. "Saving the university on his own time: Stanley Fish, service learning and knowledge legitimation in the academy." Michigan Journal of Service Learning 15 (1): 62-69.

Caduff, Carlo. 2011. "Anthropology's ethics: Moral positionalism, cultural relativism, and critical analysis." Anthropological Theory 11 (4): 465-80.

Castañeda, Quetzil E. 2006. "Ethnography in the forest: An analysis of ethics in the morals of anthropology." Cultural Anthropology 21 (1): 121-45.

Cramer, Katherine J. 2016. The politics of resentment: Rural consciousness in Wisconsin and the rise of Scott Walker. Chicago: University of Chicago Press.

D’Andrade, Roy. 1995. "Moral models in anthropology." Current Anthropology 36 (3): 399-408.

Das, Veena. 2006. Life and word: Violence and the descent into the ordinary. Berkeley: University of California Press.

Davis, Kathy. 1995. Reshaping the female body: The dilemma of cosmetic surgery. New York: Routledge.

Dehli, Kari, and Alison Taylor. 2006. "Toward new government of education research: Refashioning researchers as entrepreneurial and ethical subjects." In World yearbook of education 2006: Education research and policy-steering the knowledge-based economy, edited by Jenny Ozga, Terri Seddon, and Thomas S. Popkewitz, 105-18. London: Routledge.

de Laet, Marianne, and Annemarie Mol. 2000. “The Zimbabwe bush pump: Mechanics of a fluid technology." Social Studies of Science 30 (2): 225-63. 
Dennis, Simone. 2016. Smokefree: A social, moral and political atmosphere. London: Bloomsbury.

Edel, Abraham, and May Edel. 1959. Anthropology and ethics: The quest for moral understanding. New Brunswick, NJ: Transaction Publishers.

Edwards, Jeanette, Angelique Haugerud, and Shanti Parikh. 2016. "Introduction: The 2016 Brexit referendum and Trump election." American Ethnologist 44 (2): 195-200.

Evans-Pritchard, Edward E. 1946. “Applied anthropology.” Africa 16 (2): 92-98.

Fassin, Didier. 2008. "Beyond good and evil? Questioning the anthropological discomfort with morals." Anthropological Theory 8 (4): 333-44.

_. 2012. "Introduction: Toward a critical moral anthropology." In A companion to moral anthropology, edited by Didier Fassin, 1-17. Hoboken, NJ: Wiley.

Fish, Stanley. 2008. Save the world on your own time. Oxford: Oxford University Press.

Freud, Sigmund. (1912) 1958. "The dynamics of transference." In The standard edition of the complete psychological works of Sigmund Freud, Vol. 12. Edited by James Strachey, 97-108. London: Hogarth Press.

Garfinkel, Harold. 1967. Studies in ethnomethodology. Englewood Cliffs, NJ: Prentice Hall.

Golub, Alex. 2016. "What we learned from \#anthroboycott." Savage Minds (June 11). http:// savageminds.org/2016/06/11/what-we-learned-from-anthroboycott/.

Green, Sarah, ed. 2016. "Brexit referendum: First reactions from anthropology." Forum. Social Anthropology 24 (4): 478-502.

Gusterson, Hugh. 2017. "From Brexit to Trump: Anthropology and the rise of nationalist populism". American Ethnologist 44 (2): 209-14.

Hall, Kira, Donna Goldstein, and Matthew Bruce Ingram. 2016. “The hands of Donald Trump: Entertainment, gesture, spectacle." HAU: Journal of Ethnographic Theory 6 (2): 71-100.

Hastrup, Kirsten, and Peter Elsass. 1990. "Anthropological advocacy: A contradiction in terms?" Current Anthropology 31 (3): 301-11.

Hirschkind, Charles. 2016. "A smear in disguise: Comments on Starrett." Savage Minds (March 22). http://savageminds.org/2016/03/22/a-smear-in-disguise-comments-on-starrett.

Howell, Signe. 1997. "Introduction.” In The ethnography of moralities, edited by Signe Howell, 1-23. London: Routledge.

Jovanović, Deana. 2016. "Ambivalence and the study of contradictions." HAU: Journal of Ethnographic Theory 6 (3): 1-6.

Kapferer, Bruce. 2000. "Star wars: About anthropology, culture and globalisation.” The Australian Journal of Anthropology 11 (2): 174-98.

2007. Anthropology and the dialectic of Enlightenment: A discourse on the definition and ideals of a threatened discipline." The Australian Journal of Anthropology 18 (1): 72-94.

Kierans, Ciara. 2011. "Anthropology, organ transplantation and the immune system: Resituating commodity and gift exchange." Social Science and Medicine 73: 1469-76. 
2015. "Biopolitics and capital: Poverty, mobility and the body-in transplantation in Mexico." Body and Society 21 (3): 42-65.

Latour, Bruno. 2005. Reassembling the social. Oxford: Oxford University Press.

Ledeneva, Alena. 2006. How Russia really works: the informal practices that shaped postSoviet politics and business. Ithaca, NY: Cornell University Press.

_. 2014a. "The ambivalent future of Ukraine." Cultural Anthropology: Hot Spots (October 28). https://culanth.org/fieldsights/615-the-ambivalent-future-of-ukraine.

—. 2014b. "Economies of favors or corrupt societies? Exploring the boundaries between informality and corruption." Baltic Worlds 1: 13-21.

Lock, Margaret. 2002. Twice dead: Organ transplants and the reinvention of death. Berkeley: University of California Press.

Lynch, Michael. 2000. "Against reflexivity as an academic virtue and source of privileged knowledge." Theory, Culture \& Society 17 (3): 363-75.

Mair, Michael, and Ciara Kierans. 2007. "Critical reflections on the field of tobacco research: The role of tobacco control in defining the tobacco research agenda." Critical Public Health 17 (2): 103-12.

Malinowski, Bronisław. 1922. Argonauts of the Western Pacific. London: Routledge \& Kegan Paul.

Marcus, George. 2008. “The ends of ethnography: Social/cultural anthropology's signature form of producing knowledge in transition." Cultural Anthropology 23 (1): 1-14.

Merton, Robert K. 1976. Sociological ambivalence and other essays. New York: Free Press.

Nader, Laura. 2011. "Ethnography as theory." HaU: Journal of Ethnographic Theory 1 (1): 211-19.

Nedelmann, Birgitta. 1998. “Robert K. Merton's concept of sociological ambivalence: The Florentine case of the 'man-ape." In Robert K. Merton and contemporary sociology, edited by Robert K. Merton, Carlo Mondardini, and Simonetta Tabboni, 121-37. New Brunswick, NJ: Transaction Publishers.

Osterweil, Michal. 2013. "Rethinking public anthropology through epistemic politics and theoretical practice." Cultural Anthropology 28 (4): 598-620.

Pels, Peter. 1999. "Professions of duplexity: A prehistory of ethical codes in anthropology." Current Anthropology 40 (2): 101-36.

Rabinow, Paul. 1996. Essays in the anthropology of reason. Princeton, NJ: Princeton University Press.

Rabinow, Paul, and Gaymont Bennett. 2012. Designing human practices: An experiment with synthetic biology. Chicago: University of Chicago Press.

Raulin, Michael L., and Vicktor Brenner. 1993. “Ambivalence.” In Symptoms of schizophrenia, edited by Charles G. Costello, 201-26. New York: Wiley.

Scheper-Hughes, Nancy. 1995. "The primacy of the ethical: Propositions for a militant anthropology." Current Anthropology 36 (3): 409-40. 
Sincoff, Julie B. 1990. “The psychological characteristics of ambivalent people." Clinical Psychology Review 10 (1): 43-68.

Singleton, Vicky and Mike Michael. 1993. "Actor-networks and ambivalence: General practitioners in the UK cervical screening programme." Social Studies of Science 23 (2): 227-64.

Smelser, Neil J. 1997. "The rational and the ambivalent in the social sciences: 1997 presidential address." American Sociological Review 63 (1): 1-16.

Smith, Dorothy. 2004. "Ideology, science and social relations: A reinterpretation of Marx's epistemology." European Journal of Social Theory 7 (4): 445-62.

Smith, Jessica. 2016. "Blind spots of liberal righteousnes." Cultural Anthropology: Hot Spots (January 18). https://culanth.org/fieldsights/1044-blind-spots-of-liberal-righteousness.

Spivak, Gayatri Chakravorty. 1988. "Can the subaltern speak?” In Marxism and the interpretation of culture, edited by Cary Nelson and Lawrence Grossberg, 271-313. Basingstoke: Macmillan Education.

Stacey, Judith. 1988. “Can there be a feminist ethnography?” Women's Studies International Forum 11 (1): 21-27.

Starn, Orin. 1991. "Missing the revolution: Anthropologists and the war in Peru." Cultural Anthropology 6 (1): 63-91.

Starrett, Gregory. 2016. “The symbolic violence of choice.” Anthropology News 47 (4): 5.

Strathern, Marilyn. 2005. “Universities—and society!” Anthropology in Action 12 (1): 11-19.

Teitelbaum, Benjamin. N.d. "Dyadic devotion: Toward a new immorality in ethnography." University of Colorado, Boulder.

Turner, Jonathan H. 2005. "Is public sociology such a good idea?" The American Sociologist 36 (3): $27-45$.

Turner, Bryan S. 2007. Culture, technologies and bodies: The technologies of utopia of living forever. London: Blackwell.

Wajcman, Judy. 2004. TechnoFeminism. Cambridge: Polity.

\section{Cultiver l'ambivalence: quelques considérations méthodologiques pour l'anthropologie}

Lambivalence ressentie par les anthropologues par rapport à l'engagement politique a été, ces dernières années, le sujet de nombreuses critiques internes à la discipline - une transformation qui passe souvent pour un "tournant moral". Cet essai est un plaidoyer pour l'ambivalence, qui montre ses apports à notre heuristique méthodologique. En retraçant l'histoire de ce concept, nous montrons que l'anthropologie s'est fondée sur une ambivalence épistémologique en ce qui concerne son orientation face aux problèmes sociaux. Le tournant moral représente donc une transformation fondamentale dans la façon dont l'ethnographie est conçue. Bien que la possibilité de confusion entre évaluation morale et interprétation morale a été identifiée comme un danger de cette transformation, nous ne croyons pas que 
ce problème peut être résolu en faisant simplement preuve de réflexivité, ni que tous les anthropologues en tiennent compte. Nous suggérons plutôt que cultiver une analytique fondée sur l'ambivalence est notre meilleure stratégie pour comprendre ce qui nous entoure, et elle nous apprend plus sur la nature des rapports sociaux que ce que nous pouvons espérer des positions morales pré-établies.

Ciara KiERAns is Reader of Anthropology at the University of Liverpool. Her research focuses on studies of medical knowledge and practice with emphases on the biopolitical arrangements of organ transplantation and kidney disease-the subject of her forthcoming book The transplant complex: Sickness, poverty and medicine in Mexico. She is currently working on the topic of "unexplained" kidney disease in Mexico.

\section{Ciara Kierans Department of Public Health and Policy University of Liverpool 3rd Floor, Whelan Building Quadrangle Brownlow Hill, Liverpool L69 3GB $U K$ \\ C.Kierans@liverpool.ac.uk}

Kirsten BELL is Professor of Social Anthropology at the University of Roehampton. She has published widely in the anthropology of public health and is the author of Health and other unassailable values: Reconfigurations of health, evidence and ethics (Routledge, 2017).

Kirsten Bell

Department of Life Sciences

University of Roehampton

Whitelands College

Holybourne Avenue

London SW15 4JD

$U K$

Kirsten.Bell@roehampton.ac.uk 